\title{
SEASONAL ABUNDANCE OF DENGUE VECTORS IN RELATION TO RAINFALL AND PREVALENCE OF BREEDING CONTAINERS IN FIJI, 1981
}

\author{
MASAHIRO TAKAGI ${ }^{1}$, ISMAIL M. RAKAI ${ }^{2}$, DEO NARAYAN ${ }^{2}$, \\ RAMESH RAM ${ }^{2}$ AND GYAN PRAKASH ${ }^{2}$ \\ Received February 9 1990/Accepted April 141990
}

\begin{abstract}
A larval monitoring of dengue vectors, Aedes aegypti and Ae. pseudoscutellaris, was carried out as regularly as possible in several cities of Viti Levu, the main land of Fiji in 1981. Larval indices of both the two vector species were apparently precipitation dependent, and it was due to abundant available breeding containers. Seasonal fluctuation of those indices was more drastic in Ae. pseudoscutellaris than in Ae. aegypti. More breeding containers were found in rural area than in urban area. Performance of regular garbage collection service in urban area could reduce breeding containers for the species effectively. The variety and the density of potential containers were different in rural and urban areas. These differences were also found among industrial, commercial and residential blocks in a city, and were considered to affect species composition of the vectors.
\end{abstract}

\section{INTRODUCTION}

It has been reported by some workers that the abundance of Aedes aegypti is influenced by rainfall (Gould et al., 1970; Chan, 1973, 1985; Mogi et al., 1988), and in Fiji Goettel et al. (1980) also suggested the influence of rainfall from their results obtained by larval monitoring in Suva, the capital of this country. It has been also indicated that Ae. aegypti is endophilic and prefers to breed in artificial and rather large containers (Gould et al., 1980; Chan, 1973, 1985; Sunarto et al., 1979; Nelson et al., 1984; Knudsen, 1983). These characters of the species show a good contrast with those of Ae. albopictus, another important vector of dengue/ dengue haemorrhagic fever especially in southeast Asian countries, and result in the difference in incrimination of these species as vectors in those countries (Gould et al., 1970; Chan, 1973, 1985; Sunarto et al., 1979).

In Fiji, as in many other countries, Ae. aegypti has been considered as the most incriminatory vector mosquito for dengue/dengue haemorrhagic fever (Reed et al., 1977; Self, 1979; Miles and Mataika, 1980). Furthermore, in place of Ae. albopictus in southeast Asian countries, Ae. pseudoscutellaris, a local species, is also common in this country. This species has been suspected to play the same role as Ae. albopictus of southeast Asian countries.

1 Department of Medical Entomology, Institute of Tropical Medicine, Nagasaki University, Sakamoto-machi 12-4, Nagasaki 852, Japan

2 Vector Control Unit, Ministry of Health, Fiji Government, P.O. Box 30, Suva, Fiji This subject was supported by WHO preject No. FIJ/001. 
However, in Fiji there had been few information from temporal monitoring in some limited areas to evaluate the vector competence of the two species until 1980. Considering the above situation of the country the first large scale ecological and systematic survey of the vectors was conducted to clarify the status of infestation and roles of these species for the disease from 1980 to 1981 . We report here the seasonal abundance of the two vector species in relation to rainfall, and the prevalence of potential and available breeding sources in several areas with different environmental conditions.

\section{StUdy AREAS AND MethodS}

The data obtained by a monthly monitoring about the infestation of vectors through the house to house inspection in urban and rural areas of Suva from October 1980 to September 1981, and those obtained in two areas of Lautoka were analyzed. In the inspection, the number and type of potential and available breeding containers (available breeding containers = water holding containers among potential breeding containers) in and around more than fifty premises were recorded in each area, and the presence of vector larvae and/or pupae in the available breeding containers were examined. At least ten old larvae of the vectors were sampled by pipetting from every containers. Larval samples were identified in the laboratory, and the larval indices (container index $(\mathrm{CI})=$ number of vector larvae and/ or pupae positive containers $\times 100 /$ number of available containers inspected; premise index $(\mathrm{PI})=$ number of those positive premises $\times 100 /$ number of premises inspected; and Breteau index $(\mathrm{BI})=$ number of those positive containers $\times 100 /$ number of premises inspected) were calculated.

Suva is the biggest city and the capital of Fiji, where approximately 150 thousands people were populated. It is located in the southeast side of Viti Levu, the main island of the country, and $178^{\circ} 26^{\prime} \mathrm{E}$ and $18^{\circ} 08^{\prime} \mathrm{S}$. On the other hand Lautoka is the second biggest city, where about 75 thousands people were populated. It is located in the western side of the same island as Suva, and $177^{\circ} 27^{\prime} \mathrm{E}$ and $17^{\circ} 37^{\prime} \mathrm{S}$.

Monthly precipitation records during the investigation were collected from the Central Meteorological Office for Suva, and from Nadi International Airport for Lautoka. The airport was situated approximately $14 \mathrm{~km}$ south of Lautoka.

\section{RESULTS}

Seasonal change of larval indices of both Ae. aegypti and Ae. pseudoscutellaris were illustrated in Table 1 and Fig. 1. It is clear that all larval indices of the two aedine vectors were higher during rainy season (October-April) than those during dry season (May-September) irrespective of areas, and that the seasonal trends of the indices of both species well corresponded to the trend of monthly precipitation in both areas. Comparing with two districts, the indices except CI were higher in Suva than in Lautoka. Comparing with two species, change of the infestation between two seasons was more drastic in Ae. pseudoscutellaris (Table 1 and Fig. 1).

To examine the relation between the prevalence of both of two vectors and precipitation in detail, monthly Breteau index of two districts was plotted to monthly precipitation in equivalent areas (Fig. 2). Linear relations were confirmed between them. Especially a close 
Table 1 Seasonal change of larval indices (container index, CI; premise index, PI; and Breteau index, BI) of Aedes aegypti and Aedes pseudoscutellaris in Suva and Lautoka, Fiji

\begin{tabular}{|c|c|c|c|c|c|c|c|c|c|c|c|c|}
\hline \multirow{3}{*}{$\frac{\text { Place }}{\frac{\text { Species }}{\text { Month } \backslash \text { Indices }}}$} & \multicolumn{6}{|c|}{ Suva } & \multicolumn{6}{|c|}{ Lautoka } \\
\hline & \multicolumn{3}{|c|}{ Ae. aegypti } & \multicolumn{3}{|c|}{ Ae. pseudoscutellaris } & \multicolumn{3}{|c|}{ Ae. aegypti } & \multicolumn{3}{|c|}{ Ae. pseudoscutellaris } \\
\hline & $\mathrm{CI}$ & PI & BI & $\mathrm{CI}$ & PI & BI & $\mathrm{CI}$ & PI & BI & $\mathrm{CI}$ & PI & $\mathrm{BI}$ \\
\hline Oct. ' 80 & 34 & 50 & 105 & 45 & 75 & 122 & - & - & - & - & - & - \\
\hline Nov. & 31 & 40 & 85 & 36 & 70 & 103 & 43 & 48 & 89 & 15 & 17 & 23 \\
\hline Dec. & 17 & 48 & 90 & 18 & 44 & 89 & 40 & 29 & 56 & 14 & 13 & 16 \\
\hline Jan. '81 & 20 & 39 & 81 & 16 & 46 & 74 & 58 & 28 & 70 & 26 & 35 & 50 \\
\hline Feb. & 14 & 39 & 73 & 13 & 29 & 50 & 37 & 46 & 67 & 24 & 29 & 40 \\
\hline Mar. & 15 & 31 & 71 & 8 & 15 & 38 & 32 & 33 & 30 & 25 & 24 & 29 \\
\hline Apr. & 17 & 35 & 92 & 12 & 36 & 53 & 22 & 19 & 23 & 48 & 26 & 49 \\
\hline May & 19 & 29 & 84 & 10 & 22 & 40 & 19 & 29 & 34 & 17 & 18 & 20 \\
\hline Jun. & 28 & 27 & 68 & 8 & 20 & 26 & 20 & 24 & 40 & 2 & 5 & 4 \\
\hline Jul. & 23 & 27 & 40 & 10 & 16 & 22 & 14 & 21 & 32 & 14 & 8 & 4 \\
\hline Aug. & 17 & 29 & 49 & 7 & 12 & 47 & 22 & 26 & 45 & 19 & 21 & 20 \\
\hline Sep. & 17 & 35 & 47 & 8 & 12 & 43 & 7 & 12 & 28 & 4 & 12 & 16 \\
\hline \multicolumn{13}{|l|}{ Average } \\
\hline Oct.-Apr. & 21.1 & 40.3 & 85.3 & 21.1 & 45.0 & 75.6 & 38.7 & 33.8 & 55.8 & 25.3 & 24.0 & 34.5 \\
\hline May-Sep. & 20.8 & 29.4 & 57.6 & 8.6 & 16.4 & 35.6 & 16.4 & 22.4 & 35.8 & 11.2 & 12.8 & 12.8 \\
\hline Allover & 21.0 & 35.8 & 73.8 & 15.9 & 33.1 & 58.9 & 28.5 & 28.6 & 46.7 & 18.9 & 18.9 & 24.6 \\
\hline
\end{tabular}

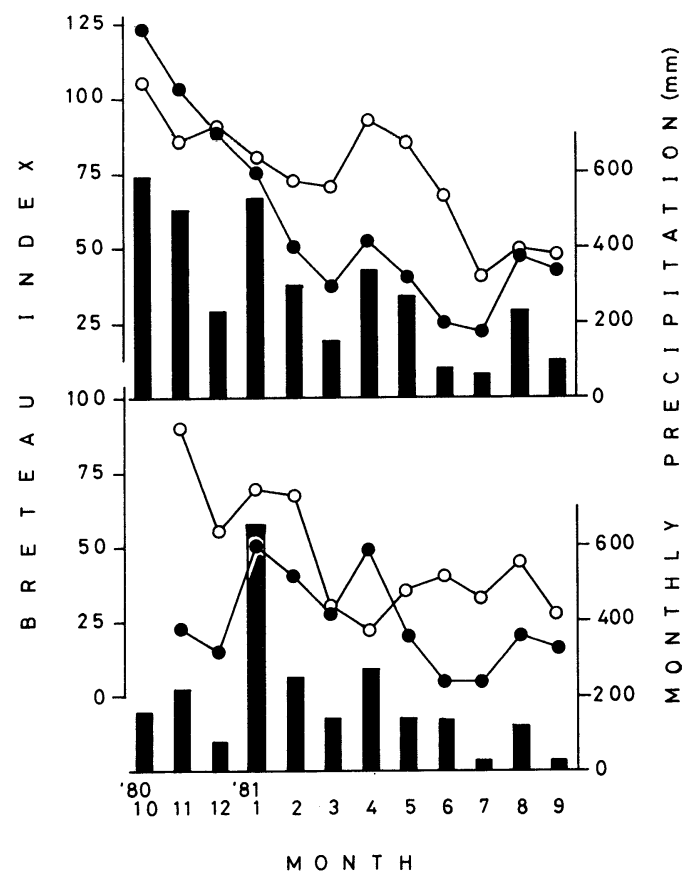

Figure 1 Seasonal change of Breteau index of Ae. aegypti (open circle) and $A e$. pseudoscutellaris (closed circle), and monthly precipitation (histogram) in Suva (upper) and in Lautoka (lower), Fiji. 
relation was found between the prevalence of Ae. pseudoscutellaris and precipitation. They fit following equations ( $\mathrm{Y}$ is Breteau index and $\mathrm{X}$ is precipitation in $\mathrm{mm}$ ): for Ae. aegypti, $\mathrm{Y}=0.082 \mathrm{X}+50.651 \quad(\mathrm{r}=0.743)$ in Suva $\mathrm{Y}=0.058 \mathrm{X}+35.789(\mathrm{r}=0.481)$ in Lautoka, and for Ae. pseudoscutellaris $\mathrm{Y}=0.146 \mathrm{X}+17.571(\mathrm{r}=0.845)$ in Suva $\mathrm{Y}=0.071 \mathrm{X}+11.263(\mathrm{r}=0.778)$ in Lautoka.

It was assumed that, if precipitation was more, the available breeding containers became more. A clear linear relation was also confirmed between the average number of available containers per premise $(\mathrm{Y})$ and the monthly precipitation $(\mathrm{X}): \mathrm{Y}=0.006 \mathrm{X}+1.610, \mathrm{r}=0.852$.

The number of available containers is not solely decided by precipitation. Artificial factors such as life style of people and conditions of sanitation should be also causative to the difference in density and diversity of breeding containers. The frequency distribution of six representative containers per premise was investigated in urban area of Suva $S(U)$, rural area of Suva S (R), urban area of Lautoka L (U), and rural area of Lautoka L (R). It was summarized in Fig. 3. Total number of available containers per premise was 6.3 in $S(R), 3.9$ in $\mathrm{S}(\mathrm{U}), 6.4$ in $\mathrm{L}(\mathrm{R})$, and 2.2 in $\mathrm{L}(\mathrm{U})$. An apparent difference was distinguished between urban area and rural area. As to the diversity of available containers, rural areas were

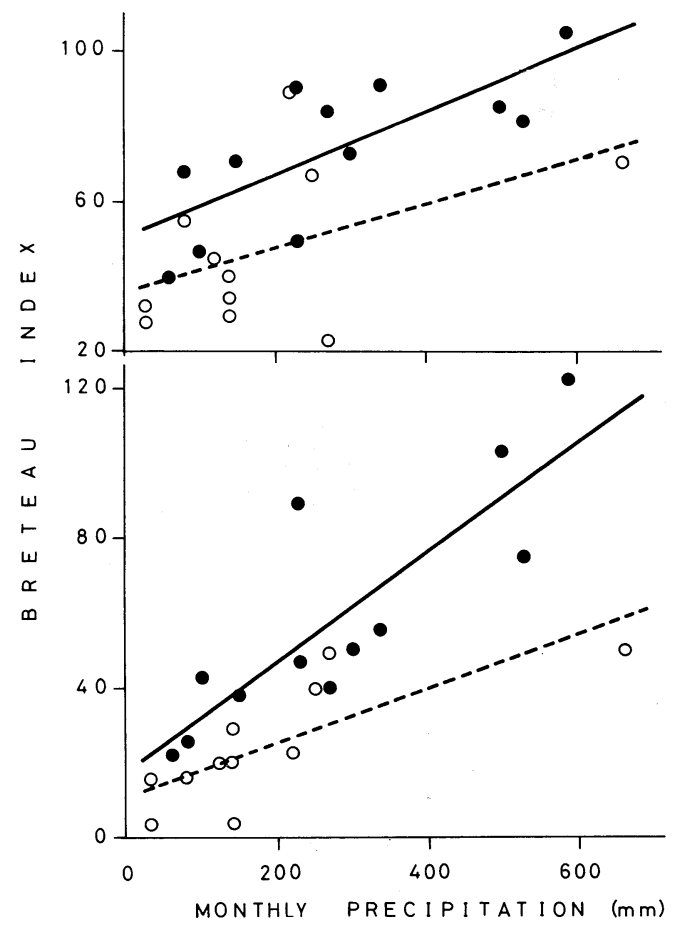

Figure 2 Relation between monthly precipitation and monthly Breteau index of $A e$. aegypti (upper) and Ae.pseudoscutellaris (lower) in Suva (closed circles and solid lines) and Lautoka (open circles and broken lines), Fiji. 
characterized by higher percentage of small containers (tin cans, empty bottles, and iron parts etc.) and drums. Little difference was found in the density of tire between two areas.

Difference in the density of available containers in the areas might cause the difference in predominance and prevalence of the two target species reflecting their oviposition preference. Table 2 shows the container index of the two species for six types of breeding containers. Actual preference for breeding containers was apparently different in the two species. As shown in Table 2, Ae. aegypti selectively bred into drums and tires, which were big in size, and water was not just temporal. On the other hand, Ae. pseudoscutellaris rather preferred to breed in small containers, but did not show strong preference for any particular types of containers.

Generally an urbanized area is composed by a variety of blocks with different socioeconomic functions, such as the industrial block, residential block, commercial block, and so on. We examined the vector status in four functionally different blocks in Suva. Results were summarized in Table 3 and Fig. 4. As shown in Table 3, annual average Breteau index for Ae. aegypti was undoubtedly high in an industrial block located'near a harbor. It was

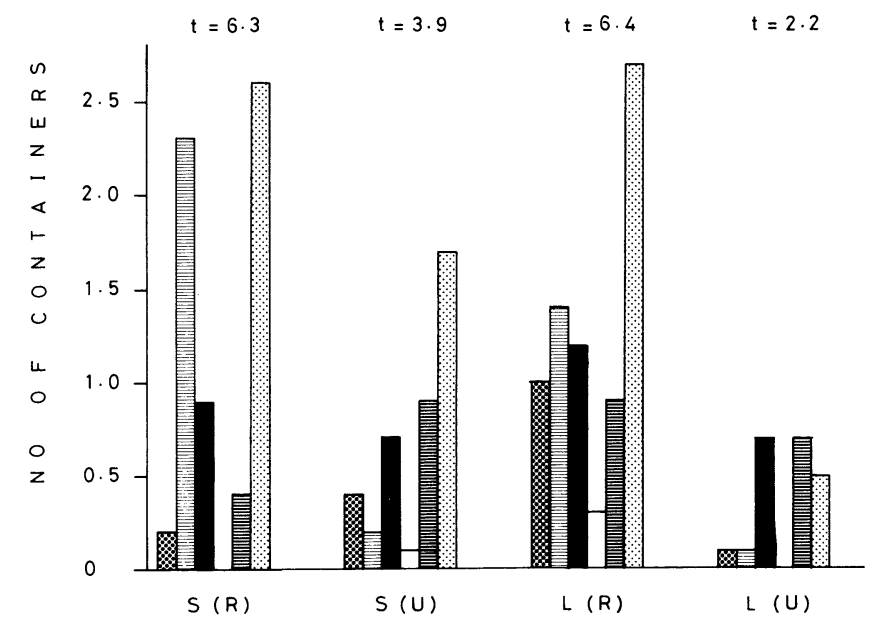

Figure 3 Average number of six types of available breeding containers per premise in rural area of Suva $(\mathrm{S}(\mathrm{R}))$, urban area of Suva $(\mathrm{S}(\mathrm{U}))$, rural area of Lautoka $(\mathrm{L}(\mathrm{R}))$ and urban area of Lautoka $(\mathrm{L}(\mathrm{U}))$, Fiji. "t" shows a total number of those containers per premise. Histograms are flower bases, drums, tires, roof gutters, planters and other small containers such as tin cans, empty bottles, sea shells and iron parts, etc. in order from the left in each area.

Table 2 Container index of Ae. aegypti and Ae.pseudoscutellaris for six types of breeding containers

\begin{tabular}{lcccccc}
\hline Containers & $\begin{array}{c}\text { Flower } \\
\text { bases }\end{array}$ & Drums & Tires & $\begin{array}{c}\text { Roof } \\
\text { gutters }\end{array}$ & Planters & $\begin{array}{c}\text { Other small } \\
\text { containers* }\end{array}$ \\
\hline Ae. aegypti & 6.3 & 25.3 & 36.8 & 1.2 & 6.5 & 9.5 \\
Ae. pseudoscutellaris & 1.3 & 11.6 & 14.8 & 0.0 & 16.5 & 21.8 \\
\hline
\end{tabular}

* Small containers include tin cans, empty bottles, sea shells and iron parts, etc. 
followed by a residential block 'L', which was composed of two apartments of five stories, and the block was mainly occupied by residents with low income. A commercial block came to the third. In a residential block of the high income ' $\mathrm{H}$ ', where premises were separated each other with a good marginal garden though almost all of them were rather older than the apartments of ' $\mathrm{L}$ ', the index was extremely low. On the other hand, the index for $A e$. pseudoscutellaris was nearly same in both of the residential blocks and the commercial block irrespective of housing conditions. Only in the industrial block, Breteau index was apparently low. The average number of six types of available breeding containers among four blocks was shows in Fig. 4. It was found by Fig. 4 that the number of available tires plus drums, which were most preferable breeding containers for Ae. aegypti, was evidently large in the industrial block, and the order among four blocks was just the same as for Breteaux index in Table 3. The number of containers other than tires and drums was not so different from each other except the industrial area.

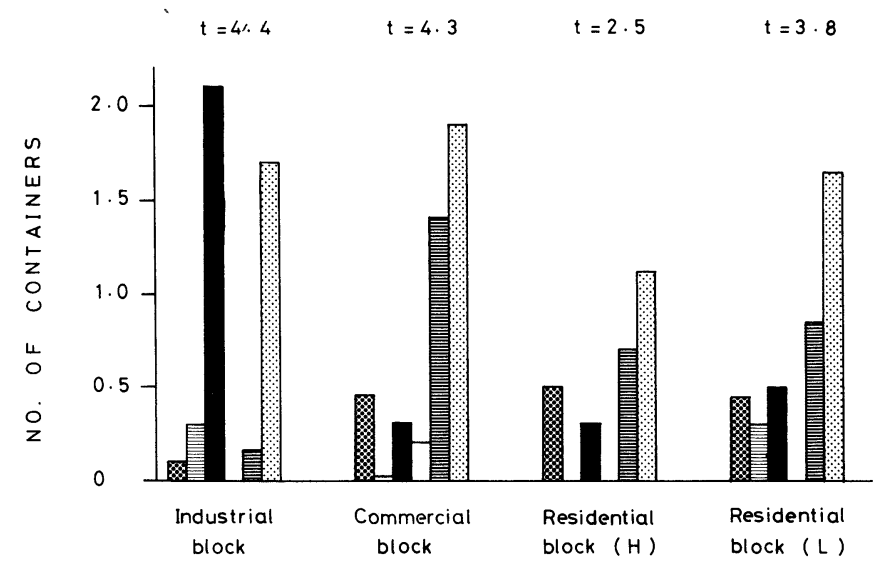

Figure 4 Average number of six types of available breeding containers per premise in industrial block, commercial block and two types of residential blocks in Suva, Fiji. "t" shows a total number of those containers per premise. Histograms are flower bases, drums, tires, roof gutters, planters and other small containers such as tin cans, empty bottles, sea shells and iron parts, etc. in order from the left in each area.

Table 3 Breteau index of Ae. aegypti and Ae. pseudoscutellaris in four town blocks with different socio-economic functions in Suva, Fiji

\begin{tabular}{lcccc}
\hline Tyecies & $\begin{array}{c}\text { Tydustrial } \\
\text { block }\end{array}$ & $\begin{array}{c}\text { Commercial block } \\
\text { block }\end{array}$ & $\begin{array}{c}\text { Residential } \\
\text { block (H) }\end{array}$ & $\begin{array}{c}\text { Residential } \\
\text { block (L) }\end{array}$ \\
\hline Ae. aegypti & 168 & 42 & 6 & 60 \\
Ae. pseudoscutellaris & 22 & 58 & 63 & 67 \\
\hline
\end{tabular}




\section{Discussion}

The difference of average larval indices between rainy season and dry season in Table 1 , and the positive regression between monthly total of precipitation and the monthly Breteau index in Fig. 2 clearly indicated that the amount of precipitation affects the incidence and abundance of Ae. aegypti and Ae. pseudoscutellaris in Fiji, as in the case of Ae. aegypti and/ or Ae. albopictus in southeast Asian countries reported by Gould et al. (1970), Chan(1973, 1985), and Mogi et al. (1988). Severer infestation by the vectors in Suva, which is in the rainy side' as called by local people, is reasonable because the annual amount of precipitation in 1981 in Suva $(3,320 \mathrm{~mm})$ was nearly twice that in surroundings of Lautoka $(1,685 \mathrm{~mm})$, which is in 'the dry side'. It was also confirmed that the number of available breeding containers actually depends on the amount of precipitation.

But the number of available containers is not only decided by precipitation but also by the artificial factors in communities reflecting the life style, condition of the sanitation, and so on. Through this survey we could draw out the vector situation in rural and urban areas in the country as such that the number of available containers, especially small containers and drums, was prominently larger in rural area. The smaller number of containers in urban area was due to the establishment of a regular garbage collection service twice a week. This service greatly contributed to reduce the number of small containers such as tin cans, empty bottles, iron parts, etc. Another feature in respect of breeding containers in rural area is abundant drums, which were usual water storage tank in the country, owing to the lacking of piping water supply system in the area. It was interesting that the frequency of tires was similar irrespective of area. These differences in the density and the diversity of containers should have caused the differences in predominance and prevalence of the two target species in the areas, as their oviposition preference was different.

The container index for six types of breeding containers was different in the two species as shown in Table 2. Ae. aegypti apparently preferred to breed into not small and not just temporal containers such as drums and tires. On the other hand, the index for Ae. pseudoscutellaris was rather high for small containers, which were abundant in rural area. The closer relation between Breteau index and the amount of precipitation in Ae. pseudoscutellaris shown in Fig. 2, may be attributed to its oviposition preference. Similar difference was observed between Ae. aegypti and Ae. albopictus by Sunarto (1979) in Indonesia.

The vector situation was different in several urban blocks with different socio-economic functions but the same amount of precipitation. The high infestation of Ae. aegypti and the high density of tires were ascertained in the industrial block.

Considering the nature of two vector species and the status of available breeding containers in the country, improvement of the environmental sanitation such as regular garbage collection and piped water supply, would be the most effective larval control measures. Among a variety of breeding containers, tires are the most incriminatory to the infestation of the vectors as they distribute to all types of area in the country with high frequency. Any counter measures to this container especially in industrial areas should be given the first priority in this country expecting effective control of Ae. aegypti. 


\section{ACKNOWLEDGMDNT}

We wish to express our sincere thanks to all those in the Fiji Ministry of Health who made this survey possible. Our thanks are also due to Dr. L.S. Self, Regional Advisor on Vector Biology and Control, Western Pacific Regional Office, WHO, for his felicitous supervision. We are also grateful to Prof. Y. Wada, Department of Medical Entomology, Institute of Tropical Medicine, Nagasaki University, for his valuable comments to the manuscript.

\section{REFERENCES}

1) Chan, K.L. (1973): Ecological approach to integrated control of Aedes aegypti and Aedes albopictus in Singapore, J. Sing. Nat. Acad. Sci., 3, 116-129

2 ) Chan, K.L. (1985): Dengue haemorrhagic fever control programme in Singapore: a case study on the successful control of Aedes aegypti and Aedes albopictus using mainly environmental measures as a part of integrated vector control, SEAMIC/IMFJ, Tokyo, 1-114

3 ) Goettel, M.S., Toohey, M.K. and Pillai, J.S. (1980): The urban mosquitoes of Suva, Fiji: seasonal incidence and evaluation of environmental sanitation and ULV spraying for their control, J. Trop. Med. Hyg., 83, 165-171

4 ) Gould, D.J., Mount, G.A., Scanlon, J.E., Ford, H.R. and Sullivan, M.F. (1970): Ecology and control of dengue vectors on an island in the Gulf of Thailand, J. Med. Entomol., 7, 499-508

5 ) Knudsen, A.B. (1983): Aedes aegypti and dengue in the Caribbean, Mosquito News, 43, 269-275

6 ) Miles, J.A.R. and Mataika, J.U. (1980): Studies of dengue and Ross River viruses in Fiji, SPC Dengue Newsletter, 6, 15-16

7 ) Mogi, M., Khamboonruang, C., Choochote, W. and Suwanpanit, P. (1988): Ovitrap surveys of dengue vector mosquitoes in Chiang Mai, northern Thailand: Seasonal shifts in relative abundance of Aedes albopictus and Ae. aegypti, Med. Veterinary Entomol., 2, 319-324

8 ) Nelson, M.J., Suarez, M.F., Morales, A., Archila, L. and Galvis, E. (1984): Aedes aegypti (L.) in rural areas of Colombia, $\mathrm{WHO} / \mathrm{VBC} / 84.890,1-10$ (unpublished document)

9) Reed, D., Maguire, T. and Mataika, J. (1977): Type 1 dengue with hemorrhagic disease in Fiji: epidemiologic findings, Am. J. Trop. Med. Hyg., 26, 784-791

10) Self, L.S. (1979): Vectors of dengue/dengue haemorrhagic fever with advances in their control, Asian J. Infect. Dis., 3, 77-79

11) Sunarto, J., Gubler, D.J., Nalim, S., Eram, S. and Saroso, J.S. (1979): Epidemic dengue hemorrhagic fever in rural Indonesia. (3) Entomological studies, Am. J. Trop. Med. Hyg., 28, $717-724$ 
フィジーにおけるデング熱媒介蚊の季節的消長と, 降雨および 幼虫発生容器の多寡の関係（1981年の調査結果）

\author{
高木 正洋 ${ }^{1}$ ・ I. M. Rakai ${ }^{2}$ - D. Narayan ${ }^{2}$ • \\ R. $\operatorname{Ram}^{2} \cdot$ G. Prakash ${ }^{2}$
}

1980年から1981年にかけて, フィジーのAedes aegypti とAe.pseudoscutellaris の発生状況と発 生原因調查を, 毎月定期的に実施した。多雨地域に位置する首都スバ市域と周辺の村落部, 少雨 地域の都市ラウトカの市域とその周辺の村落部の幼虫発生指数を検討した。発生は利用可能な容 器の密度に依存すること, 容器の密度は降雨量に依存することが確かめられた。降雨への依存程 度は,Ae. pseudoscutellaris の方が高かった。

発生容器の多寡と多様性は, 地域固有の社会経済的機能, 住民の生活様式, 公共の公衆衛生的 サービスの質に左右された。降雨量の多少に拘らず, 村落部では空き缶等の小容器とドラム缶の 密度が高かった。これはゴミの定期的収拾と, パイプ給水の未実施と関係がある。古夕イヤは工 場地帯を除けば，地域を問わずまんべんなく分布していた。自然的および人為的要因による幼虫 発生容器の存在状況の違いは, 両デング熱媒介蚊種が属性として示す産卵選好水域の違いを通し て, 両種の浸淫度の地域間差異に帰結する。ゴミを定期的に収拾する地域の拡大と古夕イヤ対策 が，同国におけるデング熱媒介蚊防除対策の要と考えた。

1 長崎大学熱帯医学研究所病害動物学部門

2 Vector Control Unit, Ministry of Health, Fiji 